\title{
The Bologna Process Could Be at Stake: Some Thoughts from Spain
}

\author{
Leoncio Vega Gil*, Juan Carlos Hernández Beltrán
}

Faculty of Education, University of Salamanca, Spain

Copyright $\bigcirc 2018$ by authors, all rights reserved. Authors agree that this article remains permanently open access under the terms of the Creative Commons Attribution License 4.0 International License

\begin{abstract}
The arrival of the Bolognia Process, that is, the last European bold adventure in order to build both a common and strong European Higher Education Area had to mean a new chance to reset our higher education structure. Bolognia meant a new opportunity to set up a wide array of reforms with the focus in raising the quality assurance. Bolognia process was supposed to be surgery rather than just make-up. In the case of Spain the approval and development of the Bolognia Process has been little impact in the much needed turn-around of the higher education arena.
\end{abstract}

Keywords Bologna Process, Spain, Higher Education

\section{Introduction}

The purpose of this study on the Bologna Process is to provide a critical analysis of both the process of institutionalizing the new undergraduate and master's degrees, and the institutional and pedagogical inertia entailed in its implementation. These categories are filtered by the equity-quality relationship in their academic practice in the creation of undergraduate curricula in educational degrees. By democratization we understand open access policies and practices based on the right to education and equal opportunities, which also aim to become the key tools for equity and social justice. Quality consists of the practices and processes for improving the training of prospective teachers, which materialize in management levers, smaller class-groups, planning by objectives, involvement of the actors, assessment through explicit and measurable formulas and criteria (standards), high requirement levels, etc.

\section{Process Design. Policy and Qualifications}

As the Eurydice 2009 study shows [1], Spain is one of the many countries in the European Union to have implemented ECTS credits through legislative regulations as part of a central government action. The political design of the Bologna Process [2] is expressed through Decree of 2007, which supported undergraduate degrees consisting of 240 credits devoted to the development of career oriented teaching and activities, and master's degrees that would provide advanced and/or specialized education [3]. However, a new government decree of 2015 on the planning of undergraduate and postgraduate studies introduced major changes. On the one hand, the training offered by undergraduate degrees should be of a generalist and basic nature, while master's degrees are intended to provide specific contents in areas of expertise. On the other hand, curricula must comprise between 180 and 240 credits, introducing flexibility in the arrangement of undergraduate and master's degrees an also interest in fostering "customized" university education.

The latest regulation for the admission of students to higher education centres was established by decree in mid-2014, according to which access requires the diploma of pre-university courses or advanced technician in vocational training, or passing the entry test for students over the age of 25 . This is another bet on the "flexible" university approach, since it does not limit the access of students from vocational training modules that mostly concentrate in certain educational undergraduate degrees with the ensuing effects on academic training processes.

Additionally, a further decree, published in 2015, regulated the requirements and conditions for the issuing of the DS (Diploma Supplement). Academic year 2015-16 marks the beginning of its issuing, since the first cohort of graduates completed their studies in the last academic year (2014-2015). The same regulation document gathers the equivalences of the Spanish Qualifications Framework for Higher Education (MECES) to the European Qualifications Framework (EQF).

The Ministry of Education has submitted the appropriate report for the recognition of such degrees at the European Higher Education Area level. However, recognition at the professional level has not yet been achieved, since it 
depends on the report and fulfilment of the requirements of the Agency responsible for managing and coordinating the EQF. This means that Spanish university degrees are recognized in the higher education framework but not in the professional qualifications framework, which entails difficulties for our qualified students when applying for bids or tenders in other European countries, a situation that is currently echoed by the media and that the Ministry of Education has promised to settle in 2016 (meaning that it will have to be addressed by the next government).

Table 1. Equivalences MECES \& EQF

\begin{tabular}{|c|c|c|}
\hline \multicolumn{2}{|c|}{ MECES } & EQF Levels \\
\hline Degrees & Levels & \\
\hline Técnico Superior (Higher Technician) & 1 & 5 \\
\hline Grado (Undergraduate Degree) & 2 & 6 \\
\hline Máster (Master's Degree) & 3 & 7 \\
\hline Doctor (PhD-Doctor's Degree) & 4 & 8 \\
\hline
\end{tabular}

Source: own elaboration

\section{Institutional Mechanisms for Implementation}

\subsection{Curricular Programmes and Academic Processes}

The creation of study curricula (launched in 2007) followed two logics, vertical for undergraduate and postgraduate degrees linked to professions regulated in the Union's framework and horizontal for undergraduate degrees lacking professional status. For undergraduate degrees following the first logic, at the appropriate time, the government issued the corresponding resolution that defined the curricular models (generic, specific and practical), the credits for each of them and the competencies to be acquired upon completion of each of them. This government suggestion, whose nature is generic due to a lack of subject or course unit as the epicentre of the curricular programme, established 50 credits for the Master's Degree in Secondary Education Teacher Training (83\% of the programme) and 210 for undergraduate degrees in Primary Education Teaching and in Early Childhood Education Teaching (87.5\%). Nevertheless, despite these common curricular guidelines, from the final structure of the different study plans it is clear that the curricula and training is not the same. The Annexes to this study provide a comparison chart matching up two universities located within the same territorial space. It shows that there are no common subject names. Common terms include "psychology", "organization" and "information and communication technologies". Why such programmatic diversity under a common competency framework? Ideally, competencies should be supported and programmed through teaching/learning processes, regardless of the framework or chart to which they belong.
However, rather than changing and adapting the curricula to Bologna "ex novo", in academic reality they were "rearranged" and "adjusted", sometimes shoehorned, to the new academic and structural requirements. Therefore, it is not a "change", but a "replacement". Inertia (undergraduate specializations are the former training specialities), corporatism, social relations, the correlation of forces and the "democratic moment" [4] have prevailed in the organizational processes of institutional decision-making. Another element in this "institutional game" is the differentiation coming from the curricula born in "full" Faculties of Education and those created in "partial" ones or in other institutional frameworks such as Schools.

The "horizontal" logic is even more open and differential, since it is not supported by a competency framework marked by government policy. In this case, there are three reform references: White Papers spread by the ANECA (National Agency for Quality Assessment and Accreditation of Spain), the comparative view of development in different European countries and the documents issued by the Board of Faculty Deans. The procedural principles applied have remained the same, albeit with slightly different results: certain curricular elements have lost strength, while others (political, comparative, methodological, didactic, psychological, sociological and practical) have gained programmatic presence. The table in the Annexes shows that certain subject names are common and that convergent terms have added relevance: "psychology", "history", "sociology" and "methodology". Thus, despite following the same institutional criteria and practices, compliance with them is paradoxically higher in the "horizontal" than in the "vertical" curricula. The longer academic tradition, higher research levels and greater institutionalization of these studies (discursive communities) may help to understand and explain some of the differences.

\subsection{Quality Management}

The academic structures of undergraduate and graduate degrees are immersed in "formal" constructs aimed at guaranteeing certain quality levels in the education they offer. First, the new curricula need to be accredited by the appropriate national agencies, the ANECA in the case of Spain. The accreditation process was, and still is, very demanding in bureaucratic terms, involving a wide range of actors in the curriculum development process (students, professional associations, employees in service, university lecturers and academic authorities). This governance has proved more formal than real, since almost all the proposed degrees have been finally approved, if not at the first opportunity, at the second. Another constituent of quality management is the "quality assurance" that is to be implemented in all degrees in accordance with the Quality Committee formed for each of them. The Committee (made up by lecturers, students and administrative staff) is 
required to draw up a two-part yearly follow-up report on the degree. The first part of the report should include the criteria for monitoring the degree (WEB presence, implementation of the quality assurance system and whether or not external evaluation reports have been taken into consideration when implementing the degree). The second part should cover the composition and work of the Quality Committee, the monitoring of the previous year's Improvements Plan, the current state of the degree (planning, development of teaching activities, mobility programmes, assessment of learning outcomes), student support services, teaching support resources (teaching organization plan, assessment of teaching staff performance, resources and services), results (quantitative and qualitative), quality assurance (job placement, levels of satisfaction of graduates and teaching staff) and up-to-date improvement plan (meaning proposals for the following academic year). The report must be supported by the corresponding "empirical evidence" (records, surveys, studies, etc., and even students' exams may be required as empirical evidence of competency assessment, to which teachers sometimes object). These improvement plans are introducing progress in the material organization of teaching practices in terms of availability and use of resources. The coordination, monitoring and fostering of this management model is in the hands of the quality units established by each university in recent years.

The third constituent of quality management is the production and delivery of the DSs (Diploma Supplement), which, given their structure and the wealth of academic information they include (personal data, structure of the higher education delivered, degree, degree level -access, duration-, curricular contents, weighted learning outcomes) are true accountability documents that also provide additional value to the degree diploma in socio-professional terms. Therefore, we are facing business and governance logics in the organization and functioning of university education and training.

\section{Pedagogical Expressions. Teaching and Research Activity}

\subsection{Planning of Teaching Processes}

Classroom level teaching practices should be planned and published in the corresponding university media through academic handbooks including detailed information on the contents and criteria established to guide teaching activities, providing valuable information to facilitate students' decision-making. Handbooks include individual "planning sheets" for each course and teacher in charge of its delivery. Paradoxically, at the University of Salamanca, the design of these "sheets" was launched by the Faculty of Geology rather than by the Faculty of
Education. Their contents gather information on the course (type, location, goals, competencies, curriculum, methodology, techniques, bibliography), the tasks to be conducted (activities, techniques), assessment (criteria, tools, recommendations, calculation), the teacher and the coursework schedule.

Nevertheless, there is still far to go until these planning tools acquire the objectivity and flexibility required by the strict educational planning with objective elements adapted to the Bologna Process [5]. In certain cases, curricula are no more than a set of curricular instructions, in others assessment is merely a pretence that lacks the rigor required by the use of objective criteria and calculation systems that students should know at the beginning of the academic year. Sometimes academic tasks merge with, or are equated to, assessment criteria, and the bibliography suggested for reference and consultation on some of the sheets is obsolete. Therefore, in a good many cases the "formal" completion of the academic planning sheets differs widely from real classroom activity, which, to a large extent, depends on day-to-day routine where no previous planning process has been required. Without advanced planning, quality in teaching/learning processes is no more than a desire or merely another part of the speech.

\subsection{Teaching/Learning Methodologies}

One of the main axes of the reform of higher education propelled by the Bologna Process is the change in teaching/learning methodologies. The proposal is to go from teaching to learning, from academic exposure to students' involvement in the acquisition of competencies, from guided knowledge to autonomous learning, from teaching contents to teaching how to learn, from teachers that instruct to educators that advise and guide, from passive to active education (according to the traditional canons of progressive education).

Nevertheless, this methodological change is proving far from easy for academic actors (teachers and students). For "old school" teachers it is hard to change their teaching, and students also find it difficult to move away from the curriculum of contents concluded and prepared to be apprehended and reproduced as required by academia. We are now witnessing a process of transition where great efforts are being made to adapt to the new requirements, while at the same time maintaining a strong focus on the quality of education and training.

Admittedly, there are at least two ways of implementing these new methodologies in the classroom [6]. On the one hand, strictly, with commitment and hard organizational efforts taking the form of a plurality of academic tasks (readings, presentations, discussions, online texts, etc.) accompanied by lectures; in other words, quality in the pursuit of the goals following new pathways. This formula requires teacher involvement to be greater than that planned for students. On the other hand, these 
methodologies may be implemented at a purely superficial level, using them to pretend to learn, assess, teach, etc., when they are really no more than just a way of "passing the time" in the classroom using videos, slides, smartboards, information searches, voicing of experiences, etc. that might lead to a mere use of "my opinion is" without any actual progress in terms of knowledge and training. Therefore, whether or not Bologna proves a means to provide a more qualitative, personalized, constructive and educational training depends, to a large extent, on teachers' outlooks and convictions.

\subsection{Technical Support Means and Resources}

The fact remains that new educational dynamics require not only greater commitment to teaching/learning processes and that new blood be infused into the teaching staff, but also more means and resources and, above all, the tools to upgrade them in order to keep pace with the technological knowledge and demands that students bring to the classroom. Smartboards, databases, the WEB, search engines, etc. become essential educational tools. But, rather than a question of ICTs as academic culture, it is about the ICT culture, meaning that they should be viewed and understood as educational tools and resources that facilitate tasks and motivate and help both teachers and students, but can never be a replacement or substitute for the actors themselves. Smartboard and blackboard must remain together in the classroom.

\subsection{Assessment/Training Processes. The Portfolio (Evidence)}

Drawing from research-action and with a long history, the teaching portfolio for the arrangement and safekeeping of educational material or evidences [7], a tool for the assessment of students' learning process, has been made popular by the Bologna process. Its aim is to gather all the materials and follow-up tasks of the learning process, therefore including exams, papers and essays, readings, students' answers through virtual tools such as "online text", attendance and participation records, reports on practical training (internal or external) and any other material resources or tasks for the monitoring of classroom education processes. The synthesis and expression of the portfolio is embodied in the "teacher chart". There has been certain reluctance to providing universities' quality units with certain evidences to include in reports and accreditation processes because of their sensitive nature, since they involve both teacher and student confidentiality and academic freedom.

Alongside empirical evidences of the training and assessment processes, what should concern us most are the criteria and methods for assessing learning outcomes and, therefore, the acquisition of the competencies envisaged in the teaching planning processes. The former are not always present or explained by task in teaching planning charts, which may be general or detailed (by task to be assessed). Nevertheless, tasks and assessment criteria are often confused, so that reading a book or article or conducting practical activities become assessment criteria when they are really basic material conditions or necessary tasks. The assessment criterion should be focused on the evaluation of advances in knowledge, personal contributions and the building/preparation involved in carrying out the task.

Another aspect of academic arrangement and planning that should be improved in several aspects is assessment methodology. On the one hand, in terms of the design and implementation of assessment tests, which should be of an instructive and educational nature, rather than just evidentiary and based on grades. Furthermore, to be able to accurately measure all the knowledge acquired through the different academic tasks, whether in or outside the classroom, calculation formulas should be rigorous, plural and quantitative. The calculation polynomial should also be clearly stated in the planning charts, so that students may be aware of it before performing the tests or undergoing continuous monitoring of the learning process. And, indeed, it should include the different forms of assessment to take into account students' personal and occupational situation, contemplating part- and full-time study.

\section{Quality and Equity Elements}

All the effort analysed above is carried out through extremely flexible selection policies based on equal opportunities and the right to education, understood as the globalization of higher education, which is in strong contradiction with the academic basics and requirements of the Bologna Process. Access to university is limited only by the availability of resources, which means that certain students might not find a place in the desired university, but will not be excluded from university education. This is all accompanied by a very generous grant policy and by enrolment fees that are socially affordable for everyone, despite the differential increase in amounts that has taken place in recent years. However, these doses of democratization of higher education are now being redirected, since already certain grant-holding students are forced to abandon their university studies because they are not able to meet the academic requirements to maintain the grant and their parents cannot pay the costs attached to university studies. It is also often the case that certain students begin their studies at universities that are far from their family home because enrolment fees are more affordable than at those nearest.

Nevertheless, the quality of education suffers severely [8], since it is frequently compelled to follow the academic tradition of theoretical and speculative education because, 
in pedagogical terms, the Bologna Process cannot be implemented in groups of 100 students per class. To pursue the goal of improving the quality of the education offered, groups should be of no more than 25-40 students. Therefore, we currently face certain academic contradictions that we do not know how to solve: on the one hand, there are too many students per class and, on the other hand, teaching staff is reduced because of the failure to fill vacancies arising from retirements. Furthermore, the number of teachers' functions has increased and, alongside teaching and conducting research, they more and more frequently carry out paperwork duties, both for research and for teaching management.

We already addressed job placement in another of our studies [9], where we approached both conferences and research on the topic focusing on two occupational groups: teaching staff and other professions. Our universities are currently undergoing a reorientation process from a Humboldt educational model to a professional paradigm defined by the Bologna Process. From the latter perspective our interest lies in learning and explaining the arrangement and working of university initiatives to pursue this requirement, policies and practices that are part of the so called "induction" and/or "mentoring" by international terminology. In this regard, there are certain universities, such as the University of Salamanca, that offer two services: one devoted to promotion, information and counselling, which is run from different points located in the different campuses; and one focused on employability, internships and job placement known as SIPPE (Service for Employability, Internships and Jobs) that, through its employment section, provides information on job offers and channels the submission of applications. The observatory facilitates reports on the follow-up of graduate students and job placement and carries out satisfaction surveys among the degree holders. Others, such as the University of Granada, have centres for the fostering of employment and internships. The section devoted to employment includes an employment observatory for job offers, a placement agency that acts as an intermediary between graduates and companies and a job vacancies site, while it also provides information to potential employers, carrying out tasks of shortlisting, recruitment, job counselling and other services. The counselling section provides training for employment and distance guidance related to jobs. This means that universities are making efforts in terms of information, counselling and intermediation between graduates and the productive system.

\section{Conclusions}

Spain, as other surrounding countries, is characterized by a political tradition of overregulation. This "regulatory patronizing" hardly leaves space for university autonomy, which should be centred in faculties and departments, or for teacher autonomy. This might be a reflection of qualitative gaps in educational and institutional processes; in other words, there is a lack of leadership and quality both in teaching and in research and, of course, in management. We have already mentioned that government action provides the framework and universities the contents. Some authors criticize the excessive bureaucracy generated by the Bologna Process which, unlike regulations, is the materialization of academic processes and, as such, a tool for equality and cohesion. Thus, rather than putting a limit on education, it serves as a tool for its protection against chaos, differences and lack of rigour in the processes.

The internal review of the institutional processes of building the new curricular structure has been led by inertial, social and "political" criteria, the latter meaning the exercise of academic power at departments and faculties, rather than by national and international academic rationality. The support of core subjects and courses is far more related to intentional atomization than to curricular and competency needs. On the other hand, study plans reflect both the "academic corporatism" and the "democracy of the moment", meaning the impact of the media on the arrangement of academic life and curricula.

In Spain, the Bologna Process is experiencing a "transition" process, especially in the educational area. Inertial academic power is still stronger than innovation, change and the renewal of methodologies and practices. The new information and communication technologies have arrived to "alienate" education, especially affecting "young teachers" by saturating classroom practices with slides, databases, media, films, smartboards, virtual tools, etc., a maelstrom of media that masks the message. Form gains relevance over content, seeming over being, "as if" over the building of self-knowledge. In addition to improving methodological practices to achieve quality education, there is a need for greater objectivity in educational planning and competency assessment.

The university reform involved in the Bologna Process should combine quality and equity, which is indeed possible. Nevertheless, there is a need for progress and improvement both in institutional selection processes involving pluralism, and in teaching/learning methodological processes that require more rigour and quality, which will encourage more flexibility in recruitment processes. 


\section{Annexes}

Basic training in the Undergraduate Degree in Primary Education Teaching at the universities of Salamanca and Valladolid. Comparative study (2015-16)

\begin{tabular}{|c|c|c|c|}
\hline USAL. Courses & Credits & UVA. Courses & Credits \\
\hline Developmental Psychology, Childhood and Adolescence & 6 & Developmental Psychology & 6 \\
\hline General Didactics & 6 & Curriculum and Educational Systems & 6 \\
\hline Educational Processes and Institutions & 6 & Psychoeducational Fundamentals of Attention to Diversity & 6 \\
\hline Language (French, English, German) & 6 & Guidance and Mentoring for Students and Families & 6 \\
\hline Sociology & 6 & Social Changes, Educational Changes and Interculturalism & 6 \\
\hline School Organization & 6 & School Organization and Planning & 6 \\
\hline Language Communication & 6 & Education for Peace and Equality & 6 \\
\hline Educational Psychology & 6 & Psychology of Learning in Educational Contexts & 6 \\
\hline Educational Research Methodology & 6 & Methods for Research and Innovation in Education & 6 \\
\hline ICTs & 6 & ICTs in Education & 6 \\
\hline
\end{tabular}

Basic training in the Undergraduate Degree in Pedagogy at the universities of Salamanca and Granada. Comparative study (2015-16)

\begin{tabular}{|c|c|c|c|}
\hline USAL. Courses & Credits & UGR. Courses & Credits \\
\hline Developmental Psychology & 6 & Developmental Psychology & 6 \\
\hline Sociology of Education & 6 & Sociology of the Education System and Social Structure & 6 \\
\hline Theory of Education & 6 & Theory of Education & 6 \\
\hline Methodology and Research & 6 & Methodological Fundamentals of Educational Research & \\
\hline ICTs in Education & 6 & Educational Anthropology & 6 \\
\hline Communication in Education & 6 & General Didactics & 6 \\
\hline Basic Psychological Processes & 6 & Educational Psychology & 6 \\
\hline Organization and Management & 6 & Sociology of Educational Practices & 6 \\
\hline English for Education & 6 & 6 & Education for Equality and Diversity \\
\hline History of Education & Social and Cultural History of Education & 6 \\
\hline
\end{tabular}

\section{REFERENCES}

[1] Eurydice (2009). La educación superior en Europa 2009: Progresos en el Proceso de Bolonia. Madrid: Ministerio de Educación.

[2] Pereyra, M. (2006). Las Universidades españolas y el proceso de construcción del Espacio Europeo de Educación Superior. Limitaciones y perspectivas de cambio. Revista española de educación comparada, $\mathrm{n}^{\circ} 12,113-143$.

[3] Vázquez, J.A (2008). La organización de las enseñanzas de grado y postgrado. Revista de Educación, $\mathrm{n}^{0}$ extraordinario, 22-39.

[4] Novoa, A. (2003). Le comparatisme en education: mode de gouvernance ou enquete historique? En P. Laderriére et F.
Vaniscotte, L'Education Comparée: un outil pour l'Europe (57-82). Paris: L'Harmattan.

[5] Escudero, J.M (2015). Un análisis crítico del Espacio Europeo de Educación Superior como reforma de la enseñanza universitaria: los programas Verifica y Docentia en el contexto español. Educar em Revista, n 57, 81-97.

[6] Esteve, F. (2009). Bolonia y las Tic,s: de la docencia $1.0 \mathrm{al}$ aprendizaje 2.0. La cuestión universitaria, $\mathrm{n}^{\mathrm{o}}$ 5, 58-67.

[7] Atienza, E. (2009). El portafolios del profesor como instrumento de autoformación. Revista de Didáctica ELE, $\mathrm{n}^{\circ}$ 9, 1-19.

[8] Muñoz-Cantero (2014). El escenario de la calidad de la universidad española: de dónde venimos y hacia dónde vamos. Revista de formación del profesorado, 17 (3), 1-16.

[9] Vega, L. (2011). Gobernanza y políticas de formación inicial de profesores en la Europa Mediterránea. Valencia: Tirant lo Blanch. 